\title{
ТЕХНОЛОГІЇ ШТУЧНОГО ІНТЕЛЕКТУ В МЕДИЧНІЙ ПРАКТИЦІ
}

\author{
О. П. Мінцер, В. О. Романов ${ }^{1}$, І. Б. Галелюка ${ }^{1}$, О. В. Вороненко ${ }^{1}$ \\ Національна медична академія післядипломної освіти імені П. Л. Шупика \\ ${ }^{1}$ /нститут кібернетики імені В. М. Глушкова НАН України
}

\begin{abstract}
Комплексна цифровізація медицини, застосування Інтернету інтелектуальних речей, мережі медичних бездротових сенсорів відкриває широкі можливості для дистанційної підтримки відповідної якості життя хронічно хворих пацієнтів, людей похилого віку, а також спортсменів і фрахівців, які мають великі фрізичні чи психічні навантаження при виконанні службових обов'язків.

Реалізація індивідуальних дистанційних засобів підтримки якості життя включає такі складові: створення нових і використання існуючих мініатюрних медичних сенсорів, що безпосередньо зчитують медичні параметри 3 організму пацієнта, мініатюрні інтерфейси для збору та первинного оброблення медичних параметрів, отриманих від медичних сенсорів, засоби приймання-передавання даних у віддалені медичні центри, автоматизовані засоби дистанційної діагностики, інжектори з дистанційним керуванням для вводу лікарських засобів у разі критичного стану пацієнта. Сучасний стан і перспективи розвитку цих засобів розглянуто у даній публікації.
\end{abstract}

Ключові слова: штучний інтелект, цифрова медицина, дистанційний медичний монітор, телездоров'я, валідність даних.

\section{ARTIFICIAL INTELLIGENCE TECHNOLOGIES IN MEDICAL PRACTICE}

\author{
O. P. Mintser, V. O. Romanov ${ }^{1}$, I. B. Galelyuka ${ }^{1}$, O. V. Voronenko ${ }^{1}$ \\ Shupyk National Medical Academy of Postgraduate Education \\ ${ }^{1}$ V. M. Glushkov Institute of Cybernetics, NAS of Ukraine
}

\begin{abstract}
Background. The integrated digitalization of medicine, the use of the Internet of Intelligent Things, and the networks of medical wireless sensors offers ample opportunities to remotely support the appropriate quality of life of chronically ill patients, the elderly, and athletes and professionals with heavy physical or mental workloads.

Materials and methods. Results. The implementation of individual remote means of maintaining quality of life includes the following components: the creation of new and the use of existing miniature or microelectronic medical sensors that directly read medical parameters from the patient's body. Such sensors are designed to monitor body temperature, heart rate, respiration and blood pressure, read heart signals, determine skin moisture, record a fall or abrupt changes in the patient's position and other body parameters in real time, miniature interfaces for data acquisition, analog-to-digital conversion and data preprocessing of medical parameters received from medical sensors located on the patient's body, miniature data communication means to remote medical centers according to modern communication standards, automated and remote diagnostic tools with elements of artificial intelligence, remote-controlled injectors for input of medicines in case of critical condition of the patient.

Conclusions. The current state and prospects for the development of these tools are discussed in the publication.
\end{abstract}

Key words: artificial intelligence, digital medicine, remote medical monitor, telehealth, data validity.

\section{ТЕХНОЛОГИИ ИСКУССТВЕННОГО ИНТЕЛЛЕКТА В МЕДИЦИНСКОЙ ПРАКТИКЕ}

\author{
О. П. Минцер, В. А. Романов ${ }^{1}$, И. Б. Галелюка ${ }^{1}$, А. В. Вороненко ${ }^{1}$ \\ Национальная медицинская академия последипломного образования \\ ${ }^{1}$ Институт кибернетики имени В. М. Глушкова НАН Украины
}

\begin{abstract}
Комплексная цифровизация медицины, применение Интернета интеллектуальных вещей, сети медицинских беспроводных сенсоров открывает широкие возможности для дистанционной поддержки соответствующего качества жизни хронически больных пациентов, людей пожилого возраста, а также спортсменов и специалистов, которые имеют большие фризические или психические нагрузки при исполнении служебных обязанностей.

Реализация индивидуальных дистанционных средств поддержки качества жизни включает следующие составляющие: создание новых и использование существующих миниатюрных медицинских сенсоров, которые непосредственно считывают медицинские параметры из организма пациента, миниатюрные интерфейсы для сбора и первичной обработки медицинских параметров, полученных от медицинских сенсоров, средства приема-передачи данных в отдаленные медицинские центры, автоматизированные средства дистанционной диагностики, инжекторы с дистанционным управлением для ввода лекарственных средств в случае критического состояния пациента. Современное состояние и перспективы развития этих средств рассмотрены в данной публикации.
\end{abstract}

Ключевые слова: искусственный интеллект, цифровая медицина, дистанционный медицинский монитор, телездоровья, валидность данных.

(c) О. П. Мінцер, В. О. Романов, І. Б. Галелюка, О. В. Вороненко 
Вступ. Цифровізація основних напрямів людської діяльності призвела до появи цифрової медицини. Цифрова медицина в першу чергу орієнтована на попередження хвороб і забезпечення необхідної якості життя людини. Виходячи з цього, на сучасному етапі розвитку технологій штучного інтелекту (ШІ) можна виділити такі базові напрями розвитку цифрової медицини щодо розроблення та створення:

1) мобільних медичних моніторів, що побудовано на основі смарт-сенсорів для вимірювання в реальному часі основних медичних параметрів [1] і об'єднано в бездротову сенсорну мережу (БСМ);

2) мобільних засобів первинного оброблення виміряних медичних параметрів, суміщених із смарт-сенсорами, для знімання цих параметрів;

3) мобільних засобів передавання параметрів, що виміряно медичним монітором і що характеризують у реальному часі стан людини, у віддалені центри прийняття рішень;

4) дистанційно керованих носимих інжекторів для введення необхідних лікарських засобів (Л3), що підтримують життєдіяльність людини.

Зазначені технології розраховано на надання медичної допомоги мільйонам людей. Їхнє освоєння та впровадження в медичну практику вже почалося. Проте, якщо носимі медичні монітори зі смарт-сенсорами, які об'єднані у бездротові мережі, та дистанційні інжектори знаходять своє застосування, хоча ще і недоступні більшості пацієнтів, то прийняття рішення за результатами переданих у віддалені медичні центри медичних параметрів про стан пацієнтів, що перебувають під віддаленим наглядом, все ще залишається прерогативою лікаря. У таких центрах у вигляді електронних медичних карт зберігають дані про захворювання пацієнта та надані йому послуги, але сучасний рівень розвитку штучного інтелекту поки що не дає можливість таким центрам самостійно в автоматичному режимі приймати рішення про застосування того чи іншого методу надання медичної допомоги.

Мета роботи: узагальнення принципів застосування технологій штучного інтелекту в медицині.

Результати та їх обговорення. Швидкий розвиток мікроелектроніки надав можливість уже сьогодні освоїти недорогі носимі медичні монітори та забезпечити ними не тільки хронічно хворих пацієнтів, але й людей, які активно займаються спортом або зазнають великих фізичних або психологічних навантажень при виконанні своїх професійних обов'язків. Як приклад розглянемо новітні базові рішення для побудови носимих медичних моніторів, що пропонуються провідними компаніями в області мікроелектронної промисловості.

До всіх багатопараметричних носимих медичних моніторів ставлять однакові вимоги: вони повинні бути валідними, мініатюрними та працювати протягом тривалого періоду часу без заміни або підзарядки елементів автономного живлення. Щоб відповідати цим вимогам, більшість відомих компаній розробляють сімейства медичних аналогових інтерфейсів, призначених для підключення до них носимих або натільних медичних сенсорів, для реєстрації та первинного оброблення в реальному часі виміряних медичних параметрів [2]. До таких параметрів належать рівень насичення крові киснем, електрокардіограма, фотоплетизмограма, артеріальний тиск, частота дихання, температура тіла й інші, багато з яких до останнього часу вимірювалися в клінічних умовах. Моніторинг цих параметрів важливий для літніх людей, пацієнтів у післяопераційний період або пацієнтів, які перенесли важке захворювання та знаходяться в зоні ризику. Крім того, моніторинг медичних параметрів, як уже зазначалося, важливий для людей, які займаються спортом або мають великі фізичні або психологічні навантаження при виконанні своїх професійних обов'язків. Тому застосування носимих багатопараметричних медичних моніторів поза межами клінічних установ $€$ нагальною потребою сучасної медичної практики. Відзначимо, що на ринку існує досить багато носимих медичних багатопараметричних систем, які одночасно вимірюють декілька медичних параметрів. Це можуть бути монітори серцевого ритму 3 датчиками руху, монітори серцевого ритму, що суміщено з вимірювачами імпедансу шкіри та що дозволяють фіксувати стреси чи аналізувати стан пацієнта уві сні. В більшості випадків у таких моніторів кожне вимірювання виконується за допомогою окремого аналогового інтерфейсу. В результаті використовують багато однотипних інтегральних мікросхем (IMC), кожна з яких містить аналого-цифровий перетворювач (АЦП), процесор, первинне та вторинне джерела живлення й інші необхідні вузли. Це ускладнює носимий медичний монітор, збільшує його розміри, 
споживану потужність, i, що найважливіше, зменшує надійність в експлуатації. Звідси випливає висновок про доцільність заміни ряду інтерфейсних IMC однією мікросхемою, до якої може бути підключено всі носимі або натільні медичні сенсори. В якості такого прикладу розглянемо особливості сімейства групових медичних інтерфейсів ADPD4000/ADPD4001. Структурна схема цього інтерфейсу наведена на рис. 1. Інтерфейс дає можливість підключати медичні сенсори з симетричними та несиметричними вихідними каналами. Він містить 8-канальний мультиплексор, два підсилювача з програмованим коефіцієнтом підсилення, два смугових фільтра, два інтегратора, 14-розрядний АЦП із максимальною частотою вибірки 1 МГц, процесор, драйвери світлодіодів і джерела сигналів збудження.

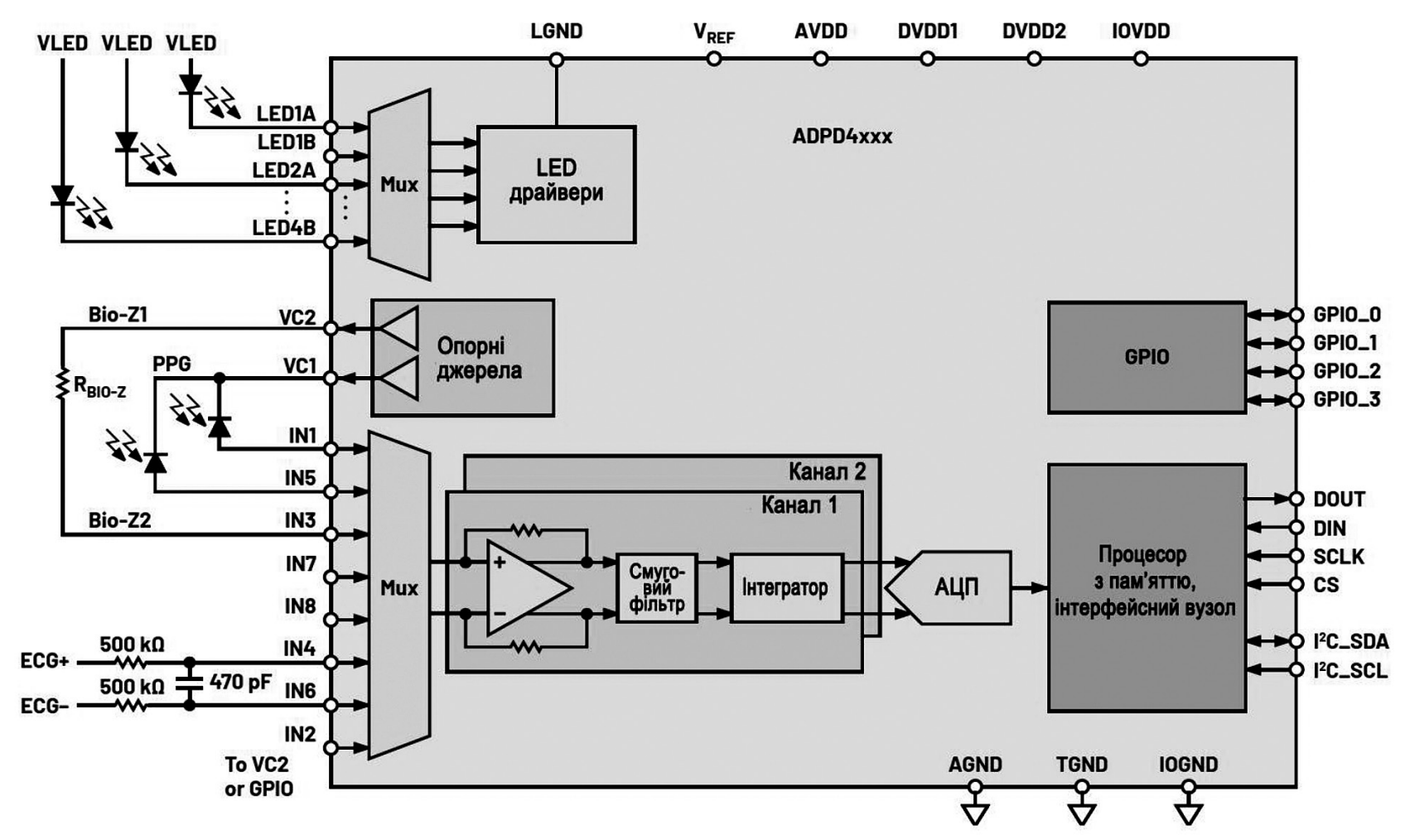

Рис. 1. Структурна схема інтерфейсу сімейства ADPD4xxx

За допомогою інтерфейсу можна вимірювати різні медичні параметри, в тому числі використовувати його як інтерфейс для оптичних сигналів, наприклад, для вимірювання частоти серцевого ритму або рівня насичення крові киснем. У цьому випадку вимірюють фотоструми низького рівня, для чого використовують вхідний підсилювальний каскад із високим імпедансом. Крім того, в носимих інтерфейсах особливу увагу слід приділити послабленню електромагнітних перешкод або перешкод, що зумовлені зовнішніми освітлювальними приладами. Цей інтерфейс можна використати для знімання та оброблення кардіосигналів. Він також формує сигнали збудження для вимірювання імпедансу шкіри (електродермальної активності) або опору електроду при вимірюванні біопотенціалів. Мікросхему інтерфейсу можна попередньо запрограмувати на одну або декілька конфігурацій, а також на знімання даних у певні часові інтервали. Цей інтерфейс не вимагає додаткових обчислювальних ресурсів для цифрового оброблення виміряних аналогових сигналів, що дає можливість мінімізувати енергоспоживання носимого монітору в цілому. Результати вимірювань медичних параметрів можна зберегти в пам’ять FIFO обсягом до 512 байт. В інтерфейсі передбачено синхронізацію вимірювань різних медичних параметрів для визначення кореляції між ними. На рис. 2 показано як цей багатопараметричний інтерфейс вимірює ЕКГ синхронно з вимірюванням пульсової хвилі (ПХ), за формою якої обчислюють артеріальний тиск, що особливо важливо для пацієнтів, які страждають гіпертонією. 

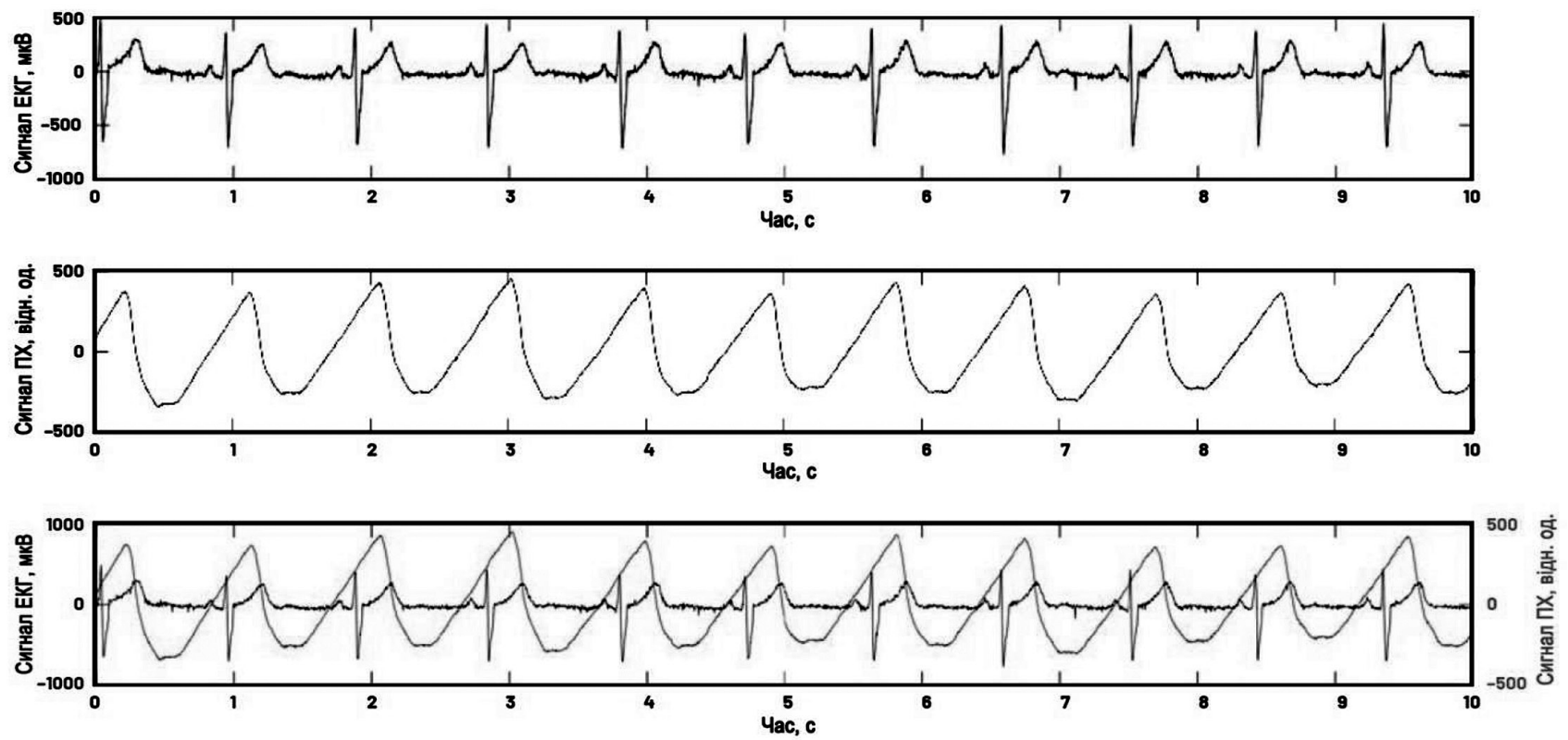

Рис. 2. Діаграми одночасного вимірювання сигналів ЕКГ і ПХ

Кардіосигнали, як правило, мають амплітуду від 0,5 мВ до 4 мВ і вимірюються у смузі частот від 0,05 до 40 Гц. Ці сигнали мають частоту серцевих скорочень, а форму самої пульсової хвилі можна використати в якості характеристики роботи серця, включаючи попередній прогноз про можливі захворювання серцевого м'яза, таких як аритмія або гіпертонія. Як відомо, роботу серцевого м’яза контролюють за допомогою змочуваних електродів, розташованих на шкірі пацієнта. При використанні поза межами клініки змочені електроди швидко висихають, а у сухих електродів контакт між шкірою й електродом може залежати від положення пацієнта, його активності, що відображається на достовірності кардіосигналу, що його знімають. Враховуючи, що при тривалому моніторингу роботи серця можна використовувати як змочувані, так і сухі електроди, інтерфейси сімейства ADPD4000 забезпечують необхідну якість вимірюваного кардіосигналу незалежно від типу таких електродів. Останнє забезпечено тим, що замість вимірювання потенціалу на виході електроду інтерфейс вимірює величину електричного заряду на конденсаторі, яка завдяки оптимальному вибору постійної часу вхідного RC-ланцюга та частоти вибірки заряду конденсатора практично не залежить від зміни опору контакту «шкіраелектрод». Ще однією перевагою IMC ADPD4000 $\epsilon$ мале енергоспоживання, оскільки вибірка, наприклад, кардіосигналу здійснюється пасивним RC-ланцюгом, тому максимальне споживання цієї
IMC складає не більше 200 мкВт. Для оптичного вимірювання пульсових хвиль у IMC ADPD4000 $€$ вісім програмованих драйверів світлодіодів. Це зумовлено тим, що в багатьох медичних системах одночасно використовують світлодіоди різної довжини хвилі. Залежно від конфігурації інтерфейс ADPD4000 забезпечує вимірювання сигналів, наприклад, серцевого ритму, рівня насичення крові киснем, рівня гідратації або дегідратації організму. Кожний із двох вхідних каналів має програмований підсилювач. Відношення сигнал/шум вхідного каналу інтерфейсу становить не менше 100 дБ, що дає можливість використовувати його при вимірюваннях, чутливих до електромагнітних завад. Багато носимих медичних моніторів призначено для вимірювання провідності шкіри, зокрема, для реєстрації електродермальної активності, стресу або психічного стану пацієнта. Сімейство IMC ADPD4000 підтримує такі вимірювання в 2- або 4-дротовому режимі. Оскільки цей інтерфейс має 8-канальний мультиплексор, його входи можна використати для вимірювання температури тіла або контролю активності пацієнта при вимірюванні медичних параметрів.

Ще одним прикладом мікроелектронного інтерфейсу для оцінювання стану серцево-судинної системи $є$ оптичний модуль ADPD188GG [3]. Добре відомо, що оцінювання стану судинного русла, включаючи капіляри, дає можливість на ранніх стадіях виявити різні хвороби серцево-судинної системи. Одним із методів скринінгової судинної 
діагностики є фотоплетизмографія. Цей експресметод засновано на визначенні обсягу крові в мікроциркуляторному руслі. Принцип дії носимих оптичних модулів для фотоплетизмографії полягає в наступному. Джерело світла, як правило, світлодіод, опромінює палець пацієнта, а фотоприймач у залежності від кількості відбитого або поглинутого тканинами організму світла вимірює форму пульсової хвилі, що зумовлено періодичною зміною обсягу крові при кожному ударі серця, а також частоту та варіабельність серцевого ритму. Коротко зупинимося на принципі роботи повністю інтегрованого оптичного модуля ADPD188GG. Світловий потік можна направити через палець або мочку вуха та вимірювати кількість пропущеного або відбитого пальцем/мочкою вуха світла (рис. 3).

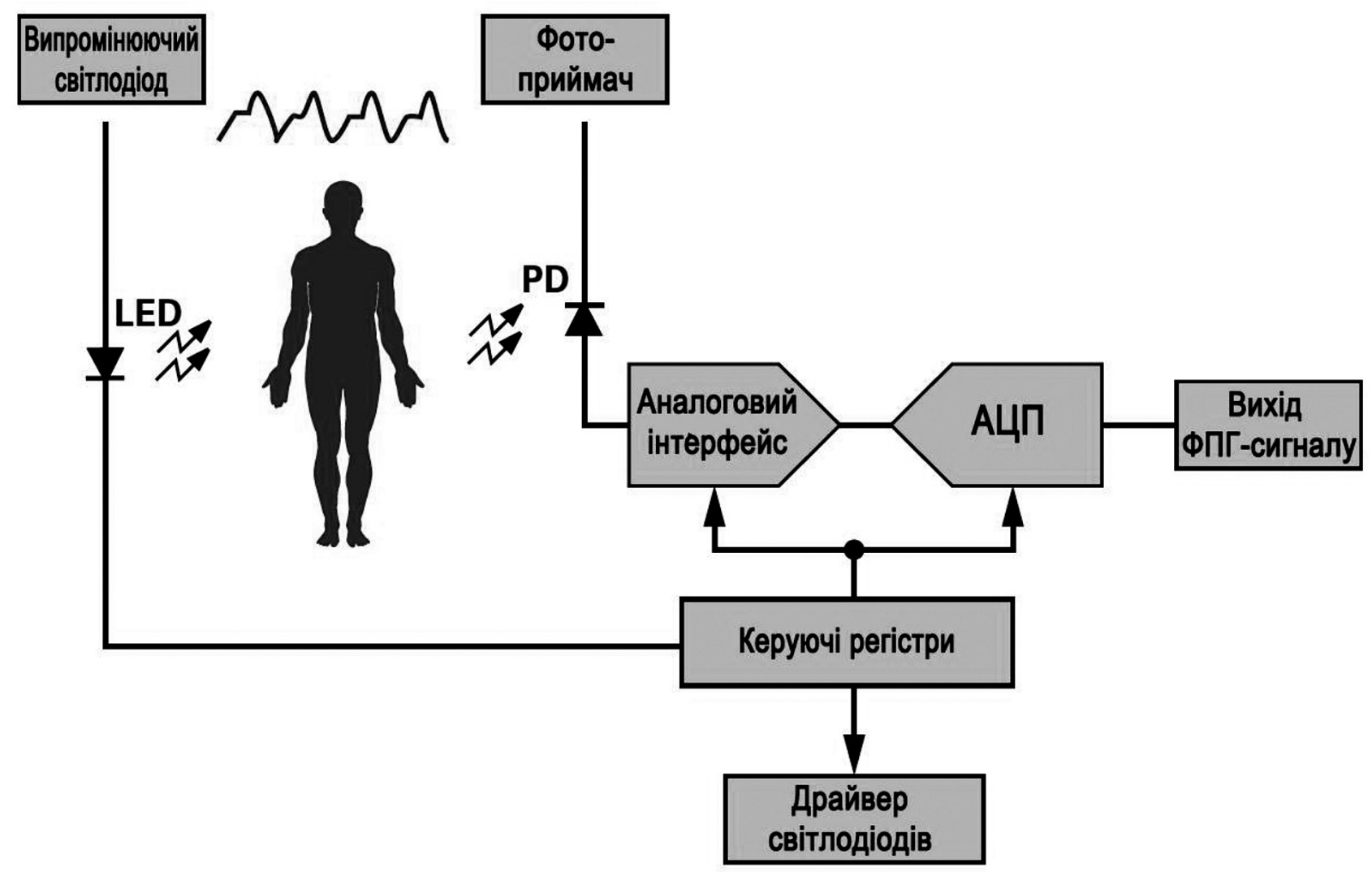

Рис. 3. Структурна схема оптичного фотоплетизмографа

Представлений мікроелектронний оптичний модуль вимірює пульсову хвилю, що іноді називають фотоплетизмограмою, на основі принципу відбиття. За час серцевих скорочень потік і обсяг крові в кровоносній системі змінюються, і це реєструється фотоприймачем відбитого світла. Важливим при цих вимірюваннях є таке положення випромінювача світла та фотоприймача, щоб забезпечувалася максимальна величина отриманого фотоприймачем сигналу. Оптичний модульADPD188GG є повністю інтегрованою оптичною системою для вимірювання пульсової хвилі. На рис. 4 наведено зовнішній вигляд цього модуля.

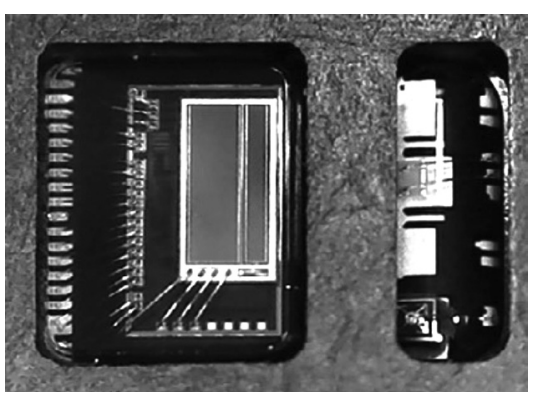

Рис. 4. Зовнішній вигляд оптичного модуля ADPD188GG для вимірювання пульсової хвилі 
Розміри ADPD188GG складають 3,98×5,0x0,9 мм. Сам фотоприймач складається з двох фотодатчиків

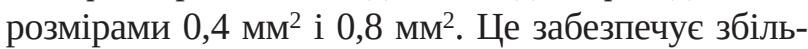
шення загальної поверхні фотоприймача та, як наслідок, підвищення його чутливості. Фотоприймач працює під управлінням аналогового інтерфейсу ADPD1080, що має чотири вхідних канали з підсилювачами та 14-розрядним АЦП. Отже, на основі оптичного модуля ADPD188GG можна побудувати носимий медичний монітор, що дасть можливість у реальному часі оцінити стан серцево-судинної системи людини, включаючи частоту серцевих скорочень, артеріальний тиск та інші медичні параметри.

Розглянуті багатопараметричні інтерфейси містять вихідні вузли для передавання послідовних цифрових кодів, що еквівалентні виміряним медичним параметрам. Це дає можливість реалізувати бездротову мережу, що підтримує передавання цифрових медичних сигналів у віддалений медичний центр.
Застосування бездротових сенсорних мереж i бездротових пристроїв у медицині дає можливість покращити якість і підвищити ефективність надання медичних послуг за рахунок можливості лікарів або когнітивних центрів дистанційно контролювати й отримувати валідну інформацію про стан пацієнта, як правило, в реальному часі для проведення діагностики та формування попереднього діагнозу. У деяких випадках при такому дистанційному медичному моніторингу пацієнт може перебувати вдома або в більш зручних для нього умовах, що позитивно впливає на його психологічний стан і сприяє позитивній динаміці лікування.

Загалом дистанційний медичний монітор пацієнта складається з певної кількості носимих (натільних) сенсорів, дистанційно керованого носимого інжектора (або інжекторів) і модуля бездротового обміну даними (рис. 5).

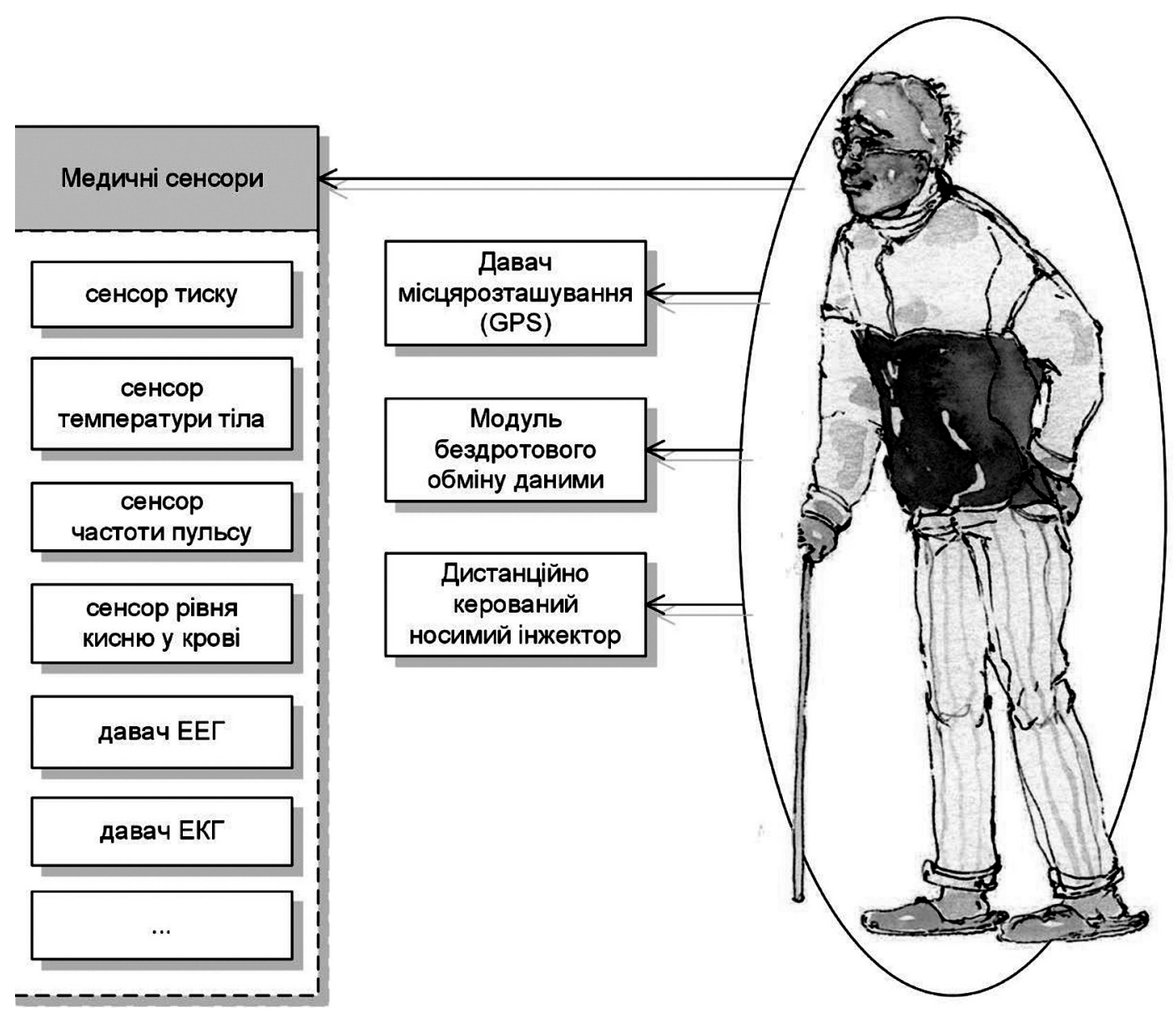

Рис. 5. Дистанційний медичний монітор пацієнта

Носимі сенсори з'єднані з модулем бездротового обміну даними через проводи або, що частіше буває, через бездротовий протокол малого радіусу дії, наприклад, Bluetooth. Часто модулем бездротового обміну даними може слугувати мобільний телефон або планшетний комп’ютер. Крім передачі даних із 
носимих сенсорів на віддалений сервер медичного закладу модуль бездротового обміну даними слугує для дистанційного керування носимими інжекторами для введення пацієнтові необхідних ЛЗ.

Слід взяти до уваги те, що дистанційний медичний моніторинг полягає не стільки в створенні каналів бездротового передавання медичних даних, скільки в організації та підтримуванні необхідної інфраструктури для функціонування систем такого моніторингу. Під цим розуміється організація Інтернет-сервісів, зберігання та захист даних на віддаленому сервері, створення прикладного програмного забезпечення, інтеграція бездротових медичних датчиків, приладів і виконавчих механізмів на рівні пацієнта, тривале функціонування бездротових датчиків і приладів у «польових» умовах практично без обслуговування, оброблення даних, у тому числі «великих даних» когнітивним діагностичним центром. Такий підхід до побудови системи дистанційного медичного моніторингу забезпечує отримання або передавання даних у режимі реального часу.

Сьогодні в світі існує багато стандартів і протоколів для бездротових систем, що доцільно використовувати в сучасних медичних системах моніторингу. Серед них можна виділити такі: Bluetooth, Bluetooth LE (або Bluetooth Smart), IEEE 802.15.4, ZigBee, Thread, WirelessHART тощо [4]. Приклад системи дистанційного медичного моніторингу, що використовує декілька протоколів бездротового обміну даними, наведено на рис. 6.

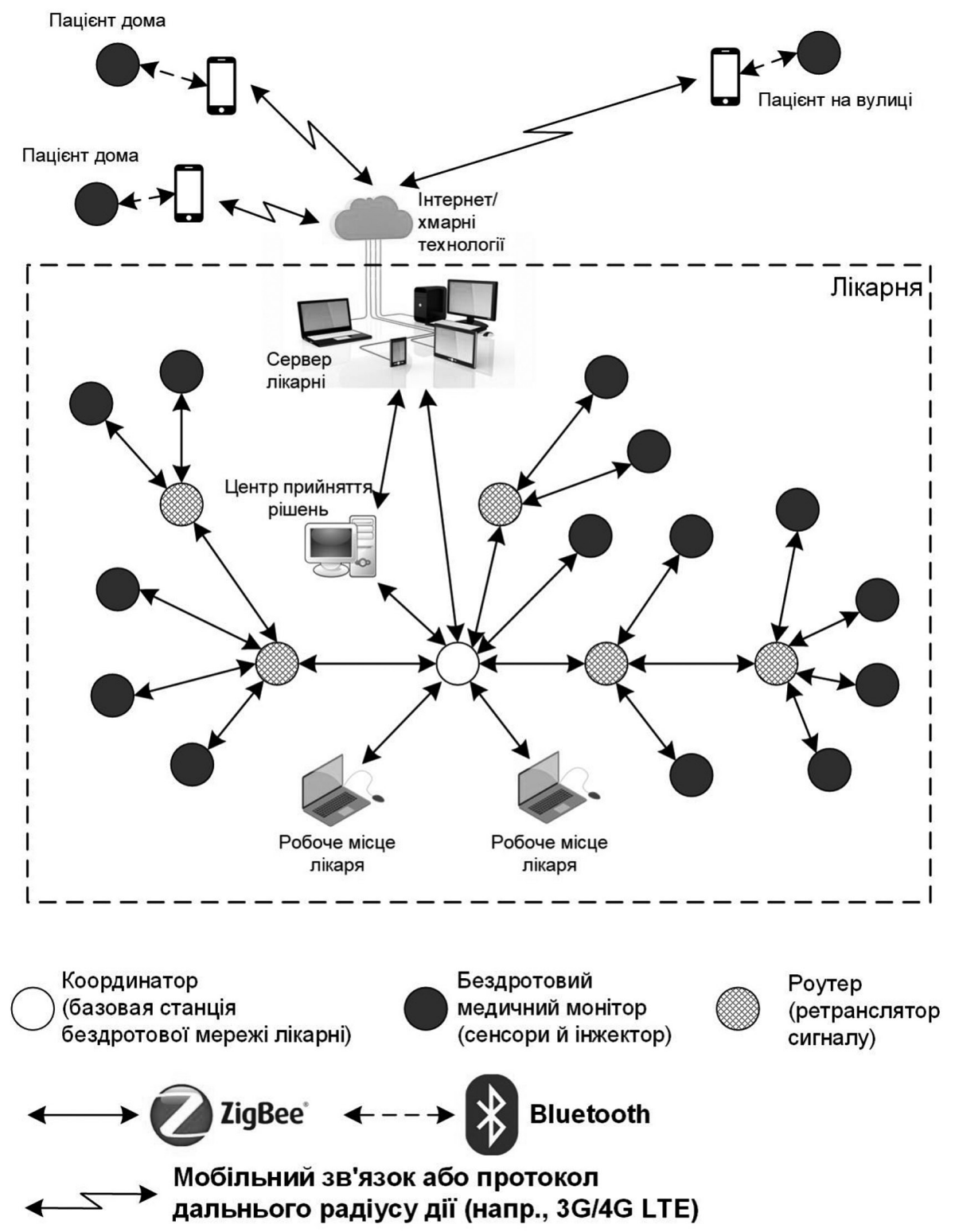

Рис. 6. Приклад системи дистанційного медичного моніторингу 
Для розроблення бездротової мережі моніторингу, що призначена для роботи в межах лікарні, можна використовувати, наприклад, протокол ZigBee. Для цього всі бездротові вузли лікарняної мережі (бездротові медичні монітори, ретранслятори сигналу та координатор мережі) можна розробляти на базі мікроконтролера JN5168 [5], що містить 32-бітний RISC-процесор із тактовою частотою 32 МГц і бездротовий модуль, сумісний зі стандартом IEEE 802.15.4. Для організації бездротового передавання даних у такій мережі було використано стек ZigBee Pro. Основним блоком управління даної мережі $є$ координатор, який забезпечує формування та роботу БСМ. Окрім того, координатор забезпечує збирання, оброблення, візуалізацію та передавання даних у віддалений центр прийняття рішення (в нашому випадку діагностичний центр). Мережевий координатор додатково може підтримувати зв'язок із хмарним середовищем, мережею Інтернет або системою більш високого рівня. Робочим місцем лікаря $є$ комп’ютер зі спеціальним адаптером ZigBee/USB.

Головним недоліком застосування ZigBee-сумісних бездротових мереж $€$ неможливість використовувати бездротові медичні монітори поза межами лікарні або її території, тобто дуже далеко від координатора мережі або ретрансляторів сигналу. Це зумовлює появу нової потреби користувачів, що полягає в можливості спостерігати за станом пацієнтів, коли вони перебувають поза межами лікарні, наприклад, удома або на вулиці досить далеко від лікарні.

Оскільки для вирішення цього завдання можливостей протоколу ZigBee не вистачає, то найкращим рішення було б модернізувати апаратне та програмне забезпечення бездротових дистанційних моніторів для підтримки бездротового обміну даними з одночасним застосуванням декількох протоколів бездротового зв'язку. Оптимальним, на нашу думку, рішенням є додавання до дистанційних моніторів засобів підтримки протоколу Bluetooth версії 5.0, зокрема з можливостями енергозбереження (BLE) для підвищення характеристик енергоефективності пристроїв.

Протокол Bluetooth версії 5.0 (і вище) має ряд вагомих переваг. Передавання даних із достатньою валідністю гарантується на відстані до 100-150 м (на відкритій території), що можна порівняти з дальністю надійного зв’ язку бездротових вузлів на основі протоколу ZigBee. У приміщеннях надійне передавання даних гарантується на відстані 30-35 м, що задовольняє умовам прикладного завдання медичного моніторингу. Максимальний розмір повідомлення становить 255 байт, що дає можливість одночасно передавати в одному пакеті декілька параметрів, що характеризують стан пацієнта. Важливим для системи медичного моніторингу $є$ можливість підключення до 20 вимірювальних вузлів у мережу типу «зірка». Для формування мережі з великим числом вимірювальних вузлів на основі протоколу Bluetooth 5.0 передбачена можливість розгортання мережі типу Bluetooth Mesh, у складі якої може бути використано від сотень до декількох тисяч вимірювальних вузлів, що дозволяє здійснювати віддалений моніторинг за станом пацієнтів великої клініки.

Апаратна модернізація передбачає заміну бездротового мікроконтролера JN5168 на новий мікроконтролер, що підтримує роботу одночасно з декількома бездротовими протоколами обміну даними, зокрема, ZigBee i Bluetooth. Для вирішення цього завдання можна обрати бездротовий мікроконтролер типу nRF52840 [6] (рис. 7).

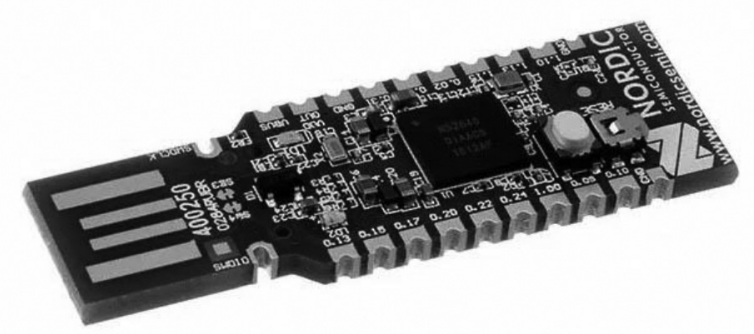

Рис. 7. Зовнішній вигляд бездротового мікроконтролера nRF52840

Цей мікроконтролер є багатопротокольним пристроєм. Він підтримує такі протоколи: Bluetooth, Thread, ZigBee, 802.15.4 тощо. Мікроконтролер спроектовано на основі 32-бітного процесора ARM Cortex-M4 із плаваючою комою та тактовою частотою 64 МГц. Він має цифрові периферійні пристрої та інтерфейси типу SPI i QSPI для сполучення із зовнішніми флеш-пам'яттю та монітором, USBпорт для передавання даних, а також вбудований зарядний пристрій для підзарядки акумулятора. 
Модернізація програмного забезпечення передбачає два варіанти реалізації. У першому варіанті мережі протокол ZigBee і протокол Bluetooth використано в непаралельному (non-concurrent) режимі. При цьому для роботи одного $з$ протоколів слід зупинити виконання іншого протоколу. Перемикання протоколів відбувається без апаратного або програмного перезавантаження бездротового модуля. Другий варіант реалізації передбачає паралельну (concurrent) реалізацію протоколів, при якій програма має доступ до обох бездротових протоколів одночасно. Перший підхід досить простий у реалізації, оскільки не вимагає застосування додаткових програмних модулів або бібліотек. Робота та перемикання різних протоколів реалізується на основі наявних інтерфейсів прикладного програмування (API) і бібліотек. Другий варіант мережі засновано на паралельній роботі протоколів ZigBee i Bluetooth. При цьому слід використовувати додаткові технології, що дають можливість прикладному програмному забезпеченню отримати одночасний доступ до двох бездротових протоколів. У такому випадку застосовують технологію «RadioTimeslot».

Бездротова система дистанційного медичного моніторингу на базі протоколу ZigBee має деревоподібну топологію. За організацію мережі відповідає координатор, який при включенні формує мережу, підключає нові бездротові монітори та управляє їхньою роботою. Зв'язок між координатором мережі та віддаленими бездротовими моніторами відбувається через роутери (ретранслятори сигналу), що в свою чергу керують локально підключеними до них кластерами бездротових моніторів. Управляти мережею або ії окремими моніторами можна тільки через координатор мережі в ручному режимі або за допомогою робочого місця лікаря (портативного або стаціонарного ПК), обладнаного адаптером ZigBee/USB. Недоліком цієї системи $€$ неможливість використовувати окремо бездротові дистанційні монітори, що самі по собі $€$ інтелектуальними пристроями.

Впровадження протоколу Bluetooth у бездротові дистанційні монітори дає можливість значно розширити функціональність і автономність як окремих моніторів, так і мережі в цілому. У такому виконанні бездротові дистанційні монітори можуть працювати не тільки в складі мережі лікарні через протокол ZigBee, але й в автономному режимі через протокол Bluetooth. При цьому користувач може управляти монітором і отримувати від нього дані через мобільний телефон або планшетний комп'ютер за допомогою протоколу Bluetooth. Через мобільний телефон і відповідний протокол дальнього зв'язку бездротовий дистанційний монітор підтримує зв'язок із віддаленим сервером лікарні, передає відповідні дані й отримує управляючі команди від сервера.

Тобто віддалені системи медичного моніторингу з елементами штучного інтелекту, такими як бездротові вимірювальні смарт-сенсори, смартінжектори, запрограмовані на введення лікарських препаратів у часі або в кризових ситуаціях, а також віддалені медичні монітори в цілому, вже сьогодні стають предметом інженерних розробок і практичного застосування, що не можна сказати про віддалені когнітивні центри діагностики та постановку діагнозу.

Важливо відзначити, що отримання даних із віддалених пристроїв далеко не вирішує проблеми прийняття рішень щодо стану пацієнта.

Спочатку потрібно відзначити технологічні проблеми. По мірі збільшення числа підключених пристроїв і обсягів обміну додатковою інформацією між пристроями також зростає і ймовірність крадіжки особистих даних (конфіденційної інформації).

Додамо, що підприємства (заклади охорони здоров’я) можуть у кінцевому підсумку мати справу з величезною кількістю (мільйонами і більше) пристроїв. Збір і управління даними 3 усіх цих пристроїв може стати складним завданням, а якщо в системі є помилка, то цілком ймовірно, що всі підключені пристрої можуть бути пошкоджені.

Нарешті, оскільки немає ніякого міжнародного стандарту сумісності для віддалених систем медичного моніторингу з елементами штучного інтелекту, то досить важко забезпечити взаємодію пристроїв від різних виробників.

Але значно більше проблем виникає щодо забезпечення валідності отриманих даних.

Останнім часом розпочала стрімко розвиватися технологія Інтернету інтелектуальних речей (IIoT), що пов'язана з використанням штучного інтелекту в комунікаційних мережах. Сенсорні мережі стають справжніми помічниками лікарів у завданнях дистанційного контролю стану пацієнтів. Зауважимо, що розумні прилади та датчики також з'являються в електронних побутових пристроях, гаджетах, мобільних телефонах або планшетах. Все це забезпечує можливість переліченим пристроям функціонувати автономно. 
Всюди проникаюча робототехніка стає реальністю, даючи можливість перейти до наступного етапу розвитку еволюції людини. Нова парадигма полягає в реалізації вирішального глобального переходу від використання технології мереж датчиків у мережу виконавчих пристроїв. Ця парадигма знаменує принципово новий підхід, бо створюється повсюдний, інтелектуальний, «живий» Інтернет. Стає можливим надавати логіку округлення даних, визначення трендів, реальних ризиків розвитку патології «звичайним приладам», і в найближчому майбутньому приймати рішення без участі людини, особливо в критичних ситуаціях.

Але кількість факторів, що беруть участь в інтегральних значеннях того чи іншого показника, досить велика. Забезпечити повноту збирання даних практично неможливо. Відповідно, в кожному клінічному випадку є ймовірність хибного результату спостережень, коли отримуючи результати від моніторингу, що мають неочікуваний характер (суттєво відрізняється від прогнозованих величин), роблять, у принципі, необгрунтовані висновки.

Отже, на сьогодні використання віддаленого сервісу спостереження за станом пацієнта можливе у випадках монопатології чи в форматі короткочасного моніторингу чи, нарешті, контрольованої процедури, що отримала назву телемедицини.

Дистанційний моніторинг (телемедицина) є найважливішим аспектом нової медицини, оскільки тривалість життя населення продовжує зростати, що, ймовірно, веде до збільшення числа пацієнтів із довгостроковими захворюваннями. Зрозуміло, що телемедицина може заощадити при медичних послугах велику кількість часу та грошей. Така телемедицина також дозволяє пацієнтам почувати себе впевнено, у разі їх підключення до персонального догляду.

Наріжним каменем цієї концепції є електронні медичні картки (ЕМК), концепція комп’ютеризованих медичних карт, що виникла ще в 1980-х роках, але стала звичайною лише в останні роки. Використання ЕМК дає можливість поліпшити координацію медичної допомоги, полегшити взаємодію 3 пацієнтами та їхніми родинами, зменшити диспропорції в охороні здоров'я, підвищити її ефективність. Це стало центральною ідеєю «телездоров'я» - пулу технологій і тактик для надання віртуальних медичних, профілактичних та освітніх послуг.

Ще однією перспективною стратегією використання віддаленого моніторингу $є$ його поєднання 3 кластером технологій, що отримала назву е-медицина (eHealth).

Подібна інтеграція може створити широкі персоналізовані медичні рішення, що можуть дозволити підключати будь-які портативні пристрої до «хмар», забезпечити аналіз зібраних даних щодо стану пацієнта в режимі реального часу; моніторинг життєво важливих показників здоров'я, зібраних за допомогою портативних пристроїв; створення діагностичних діаграм і їх візуалізацію на основі зібраних даних.

Важливо також те, що стає можливим моніторинг пацієнтів на дому за допомогою живого потокового відео й аудіо, а також за його підтримки інтелектуальні екстрені повідомлення, що надсилаються сімейному лікарю або родині.

Висновки. Сучасний розвиток інформаційних технологій, мікроелектроніки, засобів телекомунікацій та штучного інтелекту дозволяє створювати та впроваджувати індивідуальні монітори здоров'я, що можуть бути використані як хронічно хворими пацієнтами, так і фахівцями, які працюють в умовах великих фізичних та психологічних навантажень. Однак моніторинг медичних параметрів $є$ тільки однією зі складових, що дозволяють підвищити якість життя людини. Дистанційне діагностування пацієнта за отриманими медичними параметрами з використанням штучного інтелекту, надання екстреної допомоги дистанційними інжекторами та іншими виконавчими механізмами поки ще знаходяться у стадії розроблення та потребують подальшого розвитку з метою широкого застосування у медичній практиці. 


\section{Література.}

1. Інформаційні та мікроелектронні технології для застосування в мобільній медицині. Надії та обмеження / Мінцер О. П., Романов В. О., Галелюка І. Б., Антонова Г. В. // Медична інформатика та інженерія. - 2018. — № 2. - C. 13-27.

2. Broeders J.-H. Wearable Market Welcomes Biomedical All-Rounder / Broeders J.-H. — Режим доступу: www. analog.com.

3. Optical Integration without Compromises / Pálhalmi J., Broeders J.-H. — Режим доступу: www.analog.com.

4. Smart Sensors and Computer Devices for Agriculture, Food Production Process Control and Medicine / Romanov V., Galelyuka I., Voronenko O., Kovyrova O., Dzyadevych S., Shkotova L. // ICCTA 2019, 29-31 October, Alexandria, Egypt. — P. 9-12.

5. Режим доступу: https://www.nxp.com/products/ wireless/proprietary-ieee-802.15.4-based/zigbee-andieee802.15.4-wireless-microcontroller-with-256-kbflash-32-kb-ram:JN5168 (last accessed: Sept 2019).

6. Режим доступу: https://www.nordicsemi.com/Products/ Low-power-short-range-wireless/nRF52840 (last accessed: Sept 2019).

\section{References.}

1. Mintser O. P., Romanov V. A., Galelyuka I. B., Antonova A. V. (2018). Informatsiyni ta mikroelektronni tekhnolohiyi dlya zastosuvannya v mobil'niy medytsyni. Nadiyi ta obmezhennya [Information and microelectronic technologies for application in mobile medicine. Hopes and limitations]. Medichna informatika ta inzheneriya (Medical Informatics \& Engineering), 2, 13-27. [In Ukrainian].

2. Broeders J.-H. (2020). Wearable Market Welcomes Biomedical All-Rounder. Available from: www.analog.com.

3. Pálhalmi J., Broeders J.-H. (2019). Optical Integration without Compromises. Available from: www.analog.com.

4. Romanov V., Galelyuka I., Voronenko O., Kovyrova O., Dzyadevych S., Shkotova L. (2019). Smart Sensors and Computer Devices for Agriculture, Food Production Process Control and Medicine. ICCTA, 29-31 October, Alexandria, Egypt, 9-12.

5. Available from: https://www.nxp.com/products/wireless/ proprietary-ieee-802.15.4-based/zigbee-and-ieee802.15.4wireless-microcontroller-with-256-kb-flash-32-kbram:JN5168 (last accessed: Sept 2019).

6. Available from: https://www.nordicsemi.com/Products/ Low-power-short-range-wireless/nRF52840 (last accessed: Sept 2019). 